\title{
Analisis Jumlah Kuantitatif Kebutuhan Bahan Pustaka Monograp Perpustakaan IAIN Curup Berdasarkan Jumlah Mahasiswa Tahun 2019
}

\author{
Maulana Syaid $^{\mathbf{1}}$, Marleni ${ }^{2}$, Rahmat Iswanto ${ }^{3}$ \\ ${ }^{1}$ MTsN 01 Ogan Ilir Sumatera Selatan \\ ${ }^{2,3}$ Institut Agama Islam Negeri (IAIN) Curup \\ 1 e-mail: maulanasyaid8@gmail.com \\ 2e-mail: anak.nano3@gmail.com \\ 3e-mail: rahmatiswanto@iaincurup.ac.id
}

\begin{abstract}
This paper is a quantitative analysis of research on the number of library material requirements for the 2019 Curup IAIN library based on students. The purpose of this study is to obtain a quantitative amount of library material requirements for the 2019 IAIN Curup library based on students so that the numerical calculations can be evaluated and planned for meeting the needs of the visitors. The data used is data on the number of students in 2019 which is spread into several study programs and divided again based on the year of the year and the current semester. Other data used is data on the number of subjects that are billed at IAIN Curup 2019. The method used is quantitative analysis using mathematical logic. The results obtained are the number of library monograph materials with units of titles and copies seen from the number of students per semester, per year, and the accumulated number for all students of IAIN Curup in 2019. From the quantitative analysis results can be estimated in general user needs. The amount is recalculated against special circumstances regarding changes in the number of students for several reasons. This research is useful for making the design and evaluation of the policy development of the IAIN Curup library collection.
\end{abstract}

Keywords: academic library; user's needs; collection development

\begin{abstract}
Abstrak
Tulisan ini merupakan sebuah penelitian analisis kuantitatif terhadap jumlah kebutuhan bahan perpustakaan monograp perpustakaan IAIN Curup tahun 2019 berdasarkan mahasiswanya. Tujuan penelitian ini mendapatkan jumlah kuantitatif kebutuhan bahan perpustakaan monograp perpustakaan IAIN Curup tahun 2019 berdasarkan mahasiswa sehingga secara perhitungan angka dapat dilakukan evaluasi dan perencanaan terhadap pemenuhan kebutuhan
\end{abstract}


pemustaka. Data yang digunakan adalah data jumlah mahasiswa tahun 2019 yang tersebar ke dalam beberapa program studi dan dibagi kembali berdasarkan tahun angkatan dan semester berjalan. Data lain yang digunakan adalah data jumlah mata kuliah yang diagihkan pada IAIN Curup tahun 2019. Metode yang dilakukan adalah analisis kuantitatif dengan menggunakan logika matematika. Hasil yang didapatkan adalah jumlah bahan monograp perpustakaan dengan satuan judul dan eksemplar dilihat dari jumlah mahasiswa per semester, per tahun, dan akumulasi jumlah untuk seluruh mahasiswa IAIN Curup tahun 2019. Dari hasil penganalisaan secara kuantitatif dapat diperkirakan kebutuhan pemustaka secara umum. Jumlah tersebut dihitung kembali terhadap keadaan khusus mengenai perubahan jumlah mahasiswa karena beberapa hal. Penelitian ini bermanfaat untuk membuat perancangan dan evaluasi terhadap kebijakan pengembangan koleksi perpustakaan IAIN Curup.

Kata kunci: perpustakaan perguruan tinggi; kebutuhan pemustaka;pengembangan koleksi

\section{A. PENDAHULUAN}

\section{Latar Belakang}

Perpustakaan Institut Agama Islam Negeri (IAIN) Curup memiliki tugas pokok menyediakan bahan literatur bagi sivitas akademika. Penyediaan bahan literatur yang menjadi koleksi perpustakaan didasarkan dari kebutuhan pemustakanya. Pemustaka IAIN Curup adalah seluruh mahasiswa, dosen dan karyawannya. Kebutuhan pemustaka akan bahan perpustakaan dilihat dari segi kualitas dan kuantitasnya. Kualitas bahan perpustakaan maksudnya adalah jenis sumber informasi yang sesuai dengan kebutuhan pengembangan ilmu secara akademis dan ilmiah. Kuantitas bahan perpustakaan maksudnya jumlah koleksi perpustakaan secara kuantitas sesuai dengan pemustaka perpustakaan baik dengan satuan eksemplar maupun satuan judul.

Faktor yang dapat menjadi ukuran jumlah kuantitas bahan perpustakaan perguruan tinggi adalah jumlah mahasiswa yang membutuhkan ketersediaan bahan perpustakaan yang disebarkan kepada jumlah tema atau mata kuliah yang diambil oleh mereka. Setiap mahasiswa adalah pemustaka yang potensial sehingga untuk mengukur kebutuhan bahan perpustakaan dapat dilakukan dengan melakukan perhitungan secara umum. Mahasiswa IAIN Curup terdaftar ke dalam beberapa Program Studi (Prodi). Program Studi (prodi) pada IAIN Curup adalah Bimbingan Konseling Pendidikan Islam (BKPI), Manajemen Pendidikan Islam (MPI), Pendidikan Agama Islam 
(PAI), Pendidikan Bahasa Arab (BA), Pendidikan Guru Madrasah Ibtidaiyah (PGMI), Pendidikan Islam Anak Usia Dini (PIAUD), Tadris Bahasa Inggris (TBIng), Tadris Bahasa Indonesia (TBInd), Tadris Matematika (TM), Hukum Keluarga Islam (HKI), Hukum Tata Negara Islam (HTNI), Perbankan Syariah (PS), Ekonomi Syariah (ES), Bimbingan Penyuluhan Islam (BPI), Komunikasi Penyiaran Islam (KPI), Ilmu Alquran Tafsir (IAT), Ilmu Perpustakaan dan Informasi Islam (IPII).

Perpustakaan IAIN Curup memiliki koleksi monograp hingga tahun 2019 berkisar 14.000 judul dan 25.000 eksemplar yang tersebar ke dalam beberapa layanan baik layanan sirkulasi, referensi dan layanan tandon. Apakah jumlah tersebut dikategorikan telah memenuhi kebutuhan bahan perpustakaan bagi mahasiswa?

Kebutuhan bahan pustaka pada setiap perpustakaan akan berbeda berdasarkan pemustaka yang menjadi pengguna perpustakaan tersebut. Begitu juga pada perpustakaan IAIN Curup akan memiliki ukuran tertentu. Sementara pada pelaksanaan pemenuhan kebutuhan pemustaka akan bahan pustaka masih belum ada ketentuan atau pengukuran yang seyogyanya tertuang pada kebijakan pengembangan koleksi. Permasalahan ini yang akan dibahas dalam penelitian ini sehingga tergambar kebutuhan secara kuantitatif dan dapat dijadikan bahan untuk membuat kebijakan pengembangan koleksi perpustakaan IAIN Curup tahun 2020.

Untuk melakukan penelitian terkait dengan analisis jumlah kuantitatif kebutuhan bahan perpustakaan IAIN Curup maka peneliti meletakkan dua rumusan permasalahan yaitu 1). Bagaimana jumlah mahasiswa IAIN Curup tahun 2019?; dan 2) Bagaimana analisis kuantitatif kebutuhan bahan pustaka monograp berdasarkan jumlah mahasiswa IAIN Curup tahun 2019? Dengan rumusan permalahan tersebut maka penelitian ini bertujuan 1) Untuk mengetahui jumlah mahasiswa IAIN Curup tahun 2019 dan 2) Untuk mengetahui jumlah kuantitatif kebutuhan bahan pustaka berdasarkan jumlah mahasiswa IAIN Curup tahun 2019.

\section{Kontribusi}

Kontribusi atau manfaat yang diharapkan dari penelitian ini adalah manfaat secara akademik dan praktis.

Adapun manfaat secara akademiknya antara lain adalah bahwa bagi penelitian bidang perpustakaan dan informasi, dapat memperkaya khazanah penelitian terutama dalam bidang pengembangan koleksi di perpustakaan 
serta sebagai bahan rujukan untuk penelitian berikutnya yang berkaitan dengan pengembangan koleksi di perpustakaan.

Sementara manfaat secara praktisnya antara lain sebagai masukan bagi Pimpinan IAIN Curup untuk mendukung pelaksanaan evaluasi kegiatan pengembangan koleksi perpustakaan, bagi Perpustakaan Institut Agama Islam Negeri (IAIN) Curup akan menjadi formula perbaikan kebijakan pengembangan koleksi perpustakaan yang akan digunakaan dalam proses pengadaan bahan pustaka yang tepat serta bagi sivitas akademika, mendapatkan informasi ukuran bagi pemenuhan kebutuhan bahan pustaka.

\section{Kajian Teori}

Untuk mengkaji tentang jumlah kebutuhan pemustaka perpustakaan IAIN Curup, konsep yang dijelaskan antara lain pengertian pemustaka, bahan perpustakaan dan koleksi perpustakaan.

Menurut Undang-Undang Republik Indonesia Nomor 43 tahun 2007 tentang Perpustakaan, pemustaka adalah pengguna perpustakaan, yaitu perseorangan, kelompok orang, masyarakat, atau lembaga yang memanfaatkan fasilitas layanan perpustakaan. Sedangkan bahan perpustakaan adalah semua hasil karya tulis, karya cetak, dan/atau karya rekam. Adapun koleksi perpustakaan menurut Undang-Undang Republik Indonesia Nomor 43 tahun 2007 tentang Perpustakaan, koleksi perpustakaan adalah semua informasi dalam bentuk karya tulis, karya cetak, dan/atau karya rekam dalam berbagai media yang mempunyai nilai pendidikan, yang dihimpun, diolah, dan dilayankan. (Undang-Undang Republik Indonesia Nomor 43 tahun 2007 tentang Perpustakaan, 2007)

Kebutuhan pemustaka yang dimaksudkan di sini adalah kebutuhan sivitas IAIN Curup terhadap karya tulis, karya cetak, dan/atau karya rekam yang mendukung proses perkuliahan.

Peggy Johnson dalam bukunya membahas seni mengendalikan dan memperbarui koleksi perpustakaan, baik yang terletak secara lokal atau diakses dari jarak jauh. Setiap bab menawarkan liputan lengkap tentang satu aspek pengembangan dan manajemen koleksi, termasuk banyak saran untuk membaca lebih lanjut dan studi kasus naratif mengeksplorasi masalah. Pertimbangan menyeluruh diberikan pada topik manajemen tradisional seperti organisasi pengumpulan, penyiangan, kepegawaian, dan pembuatan kebijakan. Menjaga hubungan produktif dengan vendor dan penerbit, dan topik pembelian dan penganggaran penting lainnya. pengguna perpustakaan, dan peran baru untuk "penjualan" jasa ahli subyek, kegiatan penghubung, dan 
penjangkauan. Komunikasi ilmiah Johnson menawarkan tur komprehensif disiplin penting ini dan menempatkan ide-ide dasar pengembangan dan manajemen koleksi dalam perspektif historis dan teoretis, menjadikan klasik modern ini sepenuhnya terkini. (Johnson, 2014).

Manajemen koleksi dapat didefinisikan sebagai proses pengumpulan informasi, komunikasi, koordinasi, perumusan kebijakan, evaluasi, dan perencanaan yang menghasilkan keputusan tentang perolehan, penyimpanan, dan penyediaan akses ke sumber-sumber informasi dalam mendukung kebutuhan intelektual suatu diberikan komunitas perpustakaan. (Gregory, 2019)

\section{Konsep Penalaran dalam Matematika}

Matematika dipelajari dengan baik jika banyak melakukan latihan. Pelajaran matematika kurang tepat jika diajarkan dengan metode hafalan. Adapun langkah-langkah atau tahapan-tahapan proses pengkajian matematika yaitu dimulai dengan rumuskan masalah, rencanakan penyelesaian, kaji tahapan-tahapan penyelesaian, (bila data yang disajikan kurang lengkap) maka buatlah dugaan, dan juga buktikan teorema-teorema, untuk hal ini kita perlu sebuah kegiatan berpikir kritis. Dalam proses berpikir kritis, yang akan dikelolah adalah data dan atau fakta, rangkailah dalam suatu alur pemikiran yang sistematis dan logis.

Berkenaan dengan hal ini, ada dua pola penalaran yang dapat dipergunakan orang untuk menarik sebuah kesimpulan atau membuat suatu keputusan, yakni pola penalaran induktif dan pola penalaran deduktif. (Prihandoko, 2005)

\section{Penalaran Induktif}

Penalaran induktif merupakan sebuah bentuk penalaran yang berjalan dari hal-hal yang bersifat khusus ke hal-hal yang bersifat umum. Oleh karena itu proses berpikir induktif meliputi pengenalan pola, dugaan dan pembentukan generalisasi. Ketepatan sebuah dugaan atau pembentukan generalisasi dalam pola penalaran ini sangatlah tergantung dari data dan pola yang tersedia. Semakin banyak data yang diberikan atau semakin spesifik pola yang diberikan, maka akan menghasilkan sebuah dugaan atau generalisasi yang semakin mendekati kebenaran. Sebaliknya, semakin sedikit data yang diberikan atau semakin kurang spesifiknya pola yang disediakan, maka dugaan atau generalisasi bisa semakin jauh dari sasaran, dan bahkan bisa memunculkan dugaan atau generalisasi ganda. Misalkan diberikan sebuah barisan bilangan $2,5,8,11,14,17,20, \ldots$, maka pengenalan pola 
dimaksudkan sebagai suatu identifikasi tentang tata aturan penulisan barisan tersebut. Dari contoh ini dapat dilihat bahwa untuk mendapatkan bilangan berikutnya, maka sebuah bilangan dalam barisan tersebut harus ditambah dengan 3. Setelah mengetahui polanya, selanjutnya dapat dilakukan dugaandugaan tentang bilangan-bilangan yang akan muncul pada urutan yang lebih tinggi, misalnya dugaan tentang 3 bilangan yang akan muncul pada urutan ke 8,9 dan 10. Selanjutnya hasil dari proses pengenalan pola dan pendugaan tersebut dapat digunakan untuk membentuk sebuah generalisasi, yakni dengan menyusun formula untuk menentukan bilangan yang akan muncul pada urutan ke n. (Prihandoko, 2005)

\section{Penalaran Deduktif}

Jika penalaran induktif dilakukan dengan melakukan pengamatan terhadap pola-pola pada unsur-unsur khusus yang kemudian digeneralisasikan pada semua unsur dalam himpunan semesta, maka alur dalam penalaran deduktif berjalan sebaliknya. Penalaran deduktif berlangsung dari pernyataan yang berlaku secara umum yang diterapkan pada unsur-unsur khusus. Lalu bagaimana untuk mendapatkan pernyataan yang berlaku secara umum tersebut? Proses untuk membangun sebuah sistem deduktif dalam matematika diawali dengan membuat suatu konsep pangkal. Konsep pangkal ini diperlukan sebagai sarana komunikasi untuk menyusun pernyataan-pernyataan selanjutnya, baik berupa definisi, aksioma maupun teorema. Misalnya, konsep titik pada geometri. Selanjutnya kebenaran suatu konsep didasarkan pada kebenaran konsep-konsep sebelumnya dan mendasari proses penyusunan konsep-konsep selanjutnya. (Prihandoko, 2005)

\section{Logika Matematika}

Beberapa konsep logika matematika yaitu Negasi, Konjungsi, Disjungsi, Implikasi, Biimplikasi, Pernyataan Ekivalen, Kuantifikasi.

Adapun kuantifikasi dibagi menjadi tiga yaitu: Kuantifikasi Universal; Kuantifikasi Eksistensial; dan Negasi Kuantifikasi.

\section{Pembelajaran Pustakawan dengan Pendekatan Induktif}

Apalagi melalui pendekatan pembelajaran yang mengenalkan pustakawan terhadap proses "pembuktian" maupun "penurunan" suatu bentuk konsep di tingkat sekolah lanjutan, maka pustakawan akan dapat menggunakan pola pikirnya dari induktif ke deduktif. Dan bahkan pada pustakawan pendekatan pembelajaran deduktif semacam itu sudah dapat dimengerti. 
Pendekatan pemikiran secara induktif juga akan membantu pustakawan lebih mengasah kemampuannya dalam berhitung. Contohnya dalam soal sebagai berikut ini $: 1,3,5,7, \ldots, \ldots, \ldots ; 30,25,20, \ldots, 10, \ldots, 0$; $1,2,4,7,11, \ldots, \ldots$

Pustakawan diajak untuk melihat pola dari bilangan-bilangan yang diketahui dalam deret yang diberikan dan dengan ketrampilannya dalam operasi penjumlahan dan pengurangan, pustakawan akan dapat menentukan bilangan-bilangan yang ditanyakan.

Berikut adalah contoh secara induktif membantu pustakawan menangkap sifat-sifat operasi penjumlahan dan perkalian : $45+15=\ldots+45$; $88+\ldots=7+88 ; 29+(11+7)=(29+\ldots)+7 ; 55+(17+\ldots)=(55+17)+$ $22 ; 11 \times 55=55 \times \ldots ; 33 \times \ldots=15 \times 33 ; 22 \times(12 \times 5)=(22 \times \ldots) \times 5 ; 51$ $\mathrm{x}(14 \mathrm{x} \ldots)=(51 \times 14) \times 22 ; \ldots \times(30 \times 11)=(5 \times 30) \times 11 ; 5 \times(11+16)=$ $(5 \times 11)+(5 \times \ldots) ; 12 \times(22+\ldots)=(12 \times 22)+(12 \times 10) ; 50 \times(20+37)=$ $(\ldots \times \ldots)+(\ldots . . . .$.$) .$

Dalam hal ini pustakawan diajak memperhatikan pola-pola yang disajikan dan setelah mengisi titik-titik dengan bilangan yang benar, maka pustakawan akan dapat melihat adanya sifat komutatif dan asosiatif pada operasi penjumlahan dan perkalian; serta sifat distributif operasi perkalian terhadap penjumlahan.

\section{Membantu Pustakawan Berpikir Deduktif}

Sarana lain yang dapat dipergunakan untuk melatih pustakawan berpikir kritis adalah dengan memberikan soal cerita. Untuk dapat menyelesaikan soal cerita pustakawan umumnya harus menggunakan penalaran secara deduktif. Pertama-tama pustakawan harus mampu meletakkan soal cerita tersebut ke dalam bentuk matematika, selanjutnya dengan konsep-konsep yang sudah dimilikinya pustakawan akan menyelesaikan bentuk tersebut. Interpretasi dari penyelesaian bentuk matematika inilah yang akhirnya digunakan sebagai jawaban terhadap soal cerita.

Coba perhatikan soal cerita berikut ini. Yuni berbelanja ke warung dengan membawa uang Rp. 80.000,- Seperempat dari uang tersebut dibelikan buah semangka yang harga perkilonya adalah Rp. 10.000,- dan buah semangka tadi akan dibagikan sama rata kepada empat orang saudaranya yang baru pulang. Berapa berat buah semangka yang diterima oleh masingmasing saudara Yuni? 


\section{Penelitian Terdahulu}

Penelitian konsep yang telah dilakukan oleh Peneliti terdahulu bersama Misroni yang berjudul "Konsep Model Formulasi Rasio Kebutuhan Bahan Perpustakaan (Analisis Kuantitatif Kebutuhan Bahan perpustakaan Sekolah Tinggi Agama Islam Negeri Curup Tahun 2017)". Tulisan tersebut bertujuan untuk menjawab beberapa permasalahan yaitu faktor-faktor apa yang menentukan kebutuhan, bagaimana formulasi rasio kebutuhan, bagaimana formulasi rasio kebutuhan pemustaka bagi Sekolah Tinggi Agama Islam Negeri Curup dan bagaimana penyimpangan koleksi terhadap kebutuhan. Jenis penelitian yang digunakan dalam penelitian ini adalah penelitian deskriptif analisis. Populasi penelitian ini adalah sivitas akademika Sekolah Tinggi Agama Islam Negeri Curup tahun 2017. Proses analisis dilakukan dengan meletakkan konsep-konsep deskriptif sehingga menciptakan sebuah rumus yang dapat digunakan untuk mengukur kebutuhan bahan perpustakaan. Faktor-faktor yang mempengaruhi penghitungan kebutuhan pokok pemustaka perpustakaan perguruan tinggi adalah jumlah pemustaka, jumlah judul penunjang setiap mata kuliah, jumlah hari aktif, jumlah pinjaman, lama waktu peminjaman, jumlah fakultas atau jurusan, jumlah program studi dan jumlah mata kuliah. Formulasi menunjukkan jumlah kebutuhan secara minimal dan maksimal. Jumlah minimal bahan perpustakaan STAIN Curup adalah 38.516 judul. Penyimpangan terjadi karena adanya kerusakan koleksi, kehilangan koleksi, koleksi yang sudah out of date, penambahan jumlah pemustaka, perkembangan perguruann tinggi, dan peminjaman bagi karyawan perguruan tinggi yang tidak terhitung sebagai pemustaka perpustakaan. Perpustakaan masih perlu melakukan komunikasi secara baik kepada pemustaka sehingga apa yang dibutuhkan mereka dapat tercatat dan dipenuhi oleh perpustakaan. (Misroni \& Iswanto, 2018)

Sebuah penelitian yang berjudul "Peningkatan Program Studi Melalui Perencanaan Strategis dalam Pemenuhan Kebutuhan Sumber Informasi Kajian Keilmuan Sivitas Akademika (Analisis Pelaksanaan di Perpustakaan Sekolah Tinggi Agama Islam Negeri Curup)" yang ditulis oleh peneliti sendiri adapun hasil penelitian adalah bahwa keberhasilan penyelenggaraan pendidikan pada Program Studi adalah sesuatu yang terus diwujudkan dan ditingkatkan dalam rangka pempersiapkan kualitas lulusan yang semakin baik. Keberhasilan dalam hal ini juga didukung oleh banyak faktor dan unsur penting. Faktor-faktor penting terdiri dari faktor internal dan ekternal Program Studi. Faktor internal meliputi kualitas input atau mahapustakawan Program Studi, kualitas tenaga pengajar, kurikulum yang 
mapan dan teruji, ruang laboratorium dan kelas yang memadai, serta evaluasi ketersediaan sumberdaya informasi bagi kajian keilmuan Program Studi. Faktor ekternal Program Studi antara lain daya dukung lembaga induk, kegiatan kerja sama, lembaga informasi penyedia sumberdaya informasi seperti perpustakaan, dan lain-lain. Perpustakaan cukup tepat disebut sebagai jantungnya perguruan tinggi dengan melihat fungsinya sebagai lembaga penyedia sumberdaya informasi yang mendukung penyediaan literatur pokok dan penunjang pelaksanaan perkuliahan. Semakin lengkap dan baik sumberdaya informasi yang disediakan oleh perpustakaan maka semakin baik pula pemenuhan kebutuhan literatur bagi Program Studi. Semakin baik literatur Program Studi yang tersedia di perpustakaan maka semakin baik pula perkembangan Program Studi. Penelitian ini mengkaji permasalahan bagaimana perencanaan strategis yang berkaitan pemenuhan kebutuhan pemustaka (sivitas akademika) di STAIN Curup. Pengujian ilmiah tentang permasalahan di atas melalui proses penelitian diskriptif kualitatif dengan menggunakan teori-teori berkaitan dan memberikan gambaran data tambahan berupa informasi pelaksanaan proses pembinaan koleksi dan tugas pustakawan yang telah dilaksanakan di Perpustakaan STAIN Curup dua tahun terakhir. Analisa diperoleh dengan informasi dari pelaku kegiatan dengan melihat kendala dan benturan-benturan terhadap teori yang ideal. Kekuatan yang dimiliki Perpustakaan STAIN Curup dalam penerapan rencana strategis yaitu anggaran rutin, SDM yang memadai, aplikasi pendukung, serta jaringan internet. Sementara hal-hal lain sangat potensial untuk dapat diwujudkaan. Kendala yang dihadapi dapat diatasi dengan proses evaluasi teratur, komunikasi yang baik, dukungan pihak pimpinan dan penyediaan fasilitas dan SDM khusus. (Iswanto, 2017)

Penelitian lain yang dapat dilihat adalah penelitian berjudul "Kebijakan Pengembangan Koleksi dan Pemanfaatannya di Perpustakaan Perguruan Tinggi (Analisis Penerapan Kebijakan Pengembangan Koleksi Perpustakaan Utama Universitas Islam Negeri Syarif Hidayatullah Jakarta)" Dengan analisis formulasi kebijakan diketahui bagaimana konteks perumusan kebijakan, pelaku-pelaku perumus kebijakan, peran Kepala Perpustakaan, sikap lembaga induk dan nilai-nilai yang mempengaruhinya. Dengan melihat implementasinya diketahui kendala-kendala yang dihadapi. Dengan mengevaluasi implementasinya diketahui sejauhmana kebijakan tersebut dapat dilaksanakan sesuai dengan sasaran. Tulisan ini dimaksudkan untuk mengkaji kebijakan pengembangan koleksi sebuah perpustakaan perguruan tinggi dan penerapannya agar dapat diketahui pemanfaatannya dalam manajemen perpustakaan dan koleksi. (Iswanto, 2017) 


\section{Pendekatan dan Jenis Penelitian}

Penelitian ini menggunakan pendekatan kualitatif. Adapun jenis penelitian adalah penelitian analisis kuantitatif.

\section{Obyek Penelitian}

Obyek pada penelitian ini adalah bahan pustaka monograp dan mahasiswa IAIN Curup.

\section{Jenis dan Sumber Data}

Jenis data pada penelitian ini ada dua yaitu data primer dan data sekunder.

Data primer adalah data yang dapat diperoleh langsung dari sumbernya. Dalam hal ini, peneliti sebagai pengumpul data. Adapun yang menjadi sumber data primernya adalah dokumentasi jumlah mahasiswa IAIN Curup tahun 2019.

Data sekunder adalah data yang bukan diusahakan sendiri pengumpulannya oleh peneliti (Marzuki, 1995). Data sekunder dapat diperoleh dari dokumentasi, buku-buku yang terkait dengan sumber pembelajaran terbuka.

\section{Teknik Pengumpulan Data}

Teknik pengumpulan data merupakan kegiatan (pekerjaan penting) dalam melakukan penelitian, peneliti mendapatkan data secara lengkap oleh karena itu diperlukan teknik pengumpulan data yaitu prosedur yang sistematik dan standar untuk memperoleh data yang diperlukan (Nazir, 1996). Ada berbagai macam teknik pengumpulan data yang digunakan dalam proses penelitian, tetapi teknik pengumpulan data yang digunakan dalam penelitian ini adalah sebagai berikut : 1) Interview atau wawancara; wawancara adalah percakapan dengan maksud tententu. Percakapan ini dilakukan oleh dua pihak yaitu pewawancara yang mengajukan pertanyaan dan yang diwawancarai yang memberikan jawaban atas pertanyaan itu. Metode ini digunakan untuk mendapatkan data-data tentang bahan pustaka dan pemustaka perpustakaan IAIN Curup. 2) Observasi ; observasi adalah suatu cara pengumpulan data dengan mengadakan pengamatan secara langsung. Observasi dilakukan pada penelitian ini adalah mengamati sumbersumber informasi yang berkaitan dengan penelitian. 3) Dokumentasi ; dokumentasi adalah metode yang digunakan untuk mencari data mengenai hal-hal atau variabel yang berupa catatan, transkip, buku dan lain sebagainya (Arikunto, 2002). 


\section{Teknik Analisis Data}

Teknik analisis data dilakukan dengan kuantitatif yaitu menghitung jumlah kebutuhan bahan perpustakaan monograp perpustakaan IAIN Curup dengan penyebaran logika matematika.

\section{B. HASIL DAN PEMBAHASAN}

\section{Jumlah mahasiswa IAIN Curup tahun 2019}

Jumlah mahasiswa IAIN Curup hingga tahun 2019 adalah 4079. Adapun rincian jumlah mahasiswa adalah sebagai berikut:

\begin{tabular}{|c|c|c|c|c|c|c|}
\hline \multirow{3}{*}{ No } & \multicolumn{6}{|c|}{ Semester } \\
\hline & Prodi & 2 & 3 & 5 & 7 & Jumlah \\
\hline & & 2019 & 2018 & 2017 & 2016 & \\
\hline 1 & BKPI & 32 & 50 & 50 & 50 & \\
\hline 2 & MPI & 37 & 70 & 70 & 70 & \\
\hline 3 & PAI & 236 & 90 & 90 & 90 & \\
\hline 4 & BA & 21 & 30 & 30 & 30 & \\
\hline 5 & PGMI & 255 & 80 & 80 & 80 & \\
\hline 6 & PIAUD & 27 & 60 & 60 & 60 & \\
\hline 7 & TBIng & 60 & 80 & 80 & 80 & \\
\hline 8 & TBInd & 32 & 60 & 60 & 60 & \\
\hline 9 & $\mathrm{TM}$ & 6 & 60 & 60 & 60 & \\
\hline 10 & HKI & 38 & 50 & 50 & 50 & \\
\hline 11 & HTNI & 20 & 60 & 60 & 60 & \\
\hline 12 & PS & 124 & 60 & 60 & 60 & \\
\hline 13 & ES & 55 & 60 & 60 & 60 & \\
\hline 14 & BPI & 2 & 40 & 40 & 40 & \\
\hline 15 & KPI & 71 & 50 & 50 & 50 & \\
\hline 16 & IAT & 17 & 50 & 50 & 50 & \\
\hline 17 & IPII & 46 & 50 & 50 & 50 & \\
\hline \multirow{2}{*}{\multicolumn{2}{|c|}{ Jumlah }} & 1079 & 1000 & 1000 & 1000 & 4079 \\
\hline & & & Total & & & \\
\hline
\end{tabular}




\section{Jumlah kebutuhan bahan pustaka monograp berdasarkan jumlah mahasiswa IAIN Curup tahun 2019}

Kebutuhan bahan perpustakaan bagi mahasiswa IAIN Curup didasarkan kepada penggunaan literatur monograp dalam rangka mengikuti perkuliahan sehingga kebutuhan mereka diukur dengan jumlah mata kuliah dan jumlah mahasiswa. Jika setiap mata kuliah dibutuhkan 1 eksemplar monograp maka setiap mahasiswa kebutuhannya 1 eksemplar monograp. Jika seorang mahasiswa mengikuti 9 mata kuliah maka kebutuhannya adalah 9 eksemplar monograp, oleh karena itu kebutuhan akan berlipat sesuai dengan jumlah mahasiswa. Jika mata kuliah adalah A dan mahasiswa adalah B maka kebutuhan adalah AxB. Menghitung jumlah kebutuhan bahan pustaka monograp berdasarkan jumlah mahasiswa IAIN Curup maka akan muncul logika matematika bahwa kebutuhan mahasiswa adalah jumlah mahasiswa. Pemikiran menggeneralisasi kebutuhan bahan pustaka monograp bagi mahasiswa IAIN Curup.

Lain halnya dalam suatu keadaan bahwa mahasiswa memiliki kategori yang berbeda dikarenakan perbedaan mata kuliah maka setiap kategori memiliki penghitungan sendiri. Dengan demikian pemikiran generalisasi tidak tepat untuk penghitungan kebutuhan. Maka dilakukan penghitungan mulai dari bentuk general hingga pada keadaan yang mendekati spesifik keadaan mahasiswa.

Bentuk pertanyaan secara umum untuk menghitung jumlah bahan pustaka monograp perpustakaan IAIN Curup antara lain adalah berapakah kebutuhan bahan perpustakaan monograp IAIN Curup jika jumlah keseluruhan mahasiswanya adalah 5000 orang? Berapakah kebutuhan bahan perpustakaan monograp IAIN Curup jika jumlah mahasiswa angkatan tahun 2019 adalah 1200 orang, angkatan tahun 2018 adalah 1500 orang? Dan seterusnya.

Sebelum menjawab pertanyaan-pertanyaan di atas, terlebih dahulu disampaikan jumlah agihan mata kuliah sebagai ukuran kebutuhan yang akan disesuaikan dengan jumlah mahasiswa. Adapun jumlah mata kuliah adalah sebagai berikut:

a. Mata Kuliah Institusi

Mata kuliah institusi adalah mata kuliah yang diagihkan kepada seluruh mahasiswa IAIN Curup dengan penyebaran yang berbeda di setiap prodi sesuai dengan kebijakan di dalam 
kurikulum masing-masing prodi. Adapun jumlah mata kuliah ini adalah 10 mata kuliah.

b. Mata Kuliah Fakultas

Mata kuliah fakultas adalah mata kuliah yang diagihkan kepada seluruh mahasiswa fakultas tertentu di IAIN Curup dengan penyebaran yang berbeda di setiap prodi sesuai dengan kebijakan di dalam kurikulum masing-masing prodi. Adapun jumlah mata kuliah ini adalah:

\begin{tabular}{lll}
\hline No. & Fakultas & Jumlah Mata Kuliah \\
1 & Tarbiyah & 8 \\
2 & UAD & 8 \\
3 & Syariah & 8 \\
\hline
\end{tabular}

Mata kuliah prodi adalah mata kuliah yang diagihkan kepada mahasiswa prodi tertentu di IAIN Curup dengan penyebaran yang berbeda di setiap prodi sesuai dengan kebijakan di dalam kurikulum masing-masing prodi. Adapun jumlah mata kuliah ini adalah:

\begin{tabular}{lllllllllll}
\hline & \multicolumn{1}{c}{ Sumlah Mata Kuliah } \\
No. & Prodi & \multicolumn{1}{c}{ Semester } \\
& & 1 & 2 & 3 & 4 & 5 & 6 & 7 & 8 & \\
\hline 1 & BKPI & 2 & 4 & 6 & 8 & 9 & 10 & 1 & 0 & 40 \\
2 & MPI & 2 & 4 & 6 & 8 & 9 & 10 & 1 & 0 & 40 \\
3 & PAI & 2 & 4 & 6 & 8 & 9 & 10 & 1 & 0 & 40 \\
4 & BA & 2 & 4 & 6 & 8 & 9 & 10 & 1 & 0 & 40 \\
5 & PGMI & 2 & 4 & 6 & 8 & 9 & 10 & 1 & 0 & 40 \\
6 & PIAUD & 2 & 4 & 6 & 8 & 9 & 10 & 1 & 0 & 40 \\
7 & TBIng & 2 & 4 & 6 & 8 & 9 & 10 & 1 & 0 & 40 \\
8 & TBInd & 2 & 4 & 6 & 8 & 9 & 10 & 1 & 0 & 40 \\
9 & TM & 2 & 4 & 6 & 8 & 9 & 10 & 1 & 0 & 40 \\
10 & HKI & 2 & 4 & 6 & 8 & 9 & 10 & 1 & 0 & 40
\end{tabular}


52 | Maulana Syaid, dkk : Analisis Jumlah Kuantitatif...

\begin{tabular}{|c|c|c|c|c|c|c|c|c|c|c|}
\hline 11 & HTNI & 2 & 4 & 6 & 8 & 9 & 10 & 1 & 0 & 40 \\
\hline 12 & PS & 2 & 4 & 6 & 8 & 9 & 10 & 1 & 0 & 40 \\
\hline 13 & ES & 2 & 4 & 6 & 8 & 9 & 10 & 1 & 0 & 40 \\
\hline 14 & BPI & 2 & 4 & 6 & 8 & 9 & 10 & 1 & 0 & 40 \\
\hline 15 & KPI & 2 & 4 & 6 & 8 & 9 & 10 & 1 & 0 & 40 \\
\hline 16 & IAT & 2 & 4 & 6 & 8 & 9 & 10 & 1 & 0 & 40 \\
\hline 17 & IPII & 2 & 4 & 6 & 8 & 9 & 10 & 1 & 0 & 40 \\
\hline \multicolumn{10}{|c|}{ Total } & 680 \\
\hline
\end{tabular}

\section{Penghitungan Secara General}

Jika jumlah kebutuhan dihitung secara general maka didapatkan penghitungan sebagai berikut:

- Akumulasi semua mahasiswa IAIN Curup

\begin{tabular}{ccccc}
\hline & & JUMLAH & JUMLAH & JUMLAH \\
NO. PRODI & SEMESTER & MAHASISWA & MATA & KEBUTUHAN \\
KULIAH & (EKS)
\end{tabular}
B
A
(BXA)

SEMUA

1 PRODI

$1-7$

4936

58

286288

- Akumulasi semua mahasiswa IAIN Curup dengan penyebaran dalam prodi

\begin{tabular}{ccccc}
\hline & & JUMLAH & JUMLAH & JUMLAH \\
NO. PRODI & SEMESTER & MAHASISWA & MATA & KEBUTUHAN \\
KULIAH & (EKS)
\end{tabular}

\begin{tabular}{llcccc} 
& & & B & A & (BXA) \\
\hline 1 & BKPI & $1-7$ & 1500 & 58 & 87000 \\
2 & MPI & $1-7$ & 200 & 58 & 11600 \\
3 & PAI & $1-7$ & 500 & 58 & 29000 \\
4 & BA & $1-7$ & 200 & 58 & 11600 \\
5 & PGMI & $1-7$ & 200 & 58 & 11600 \\
6 & PIAUD & $1-7$ & 200 & 58 & 11600
\end{tabular}




$\begin{array}{rlcccc}7 & \text { TBIng } & 1-7 & 200 & 58 & 11600 \\ 8 & \text { TBInd } & 1-7 & 700 & 58 & 40600 \\ 9 & \text { TM } & 1-7 & 436 & 58 & 25288 \\ 10 & \text { HKI } & 1-7 & 100 & 58 & 5800 \\ 11 & \text { HTNI } & 1-7 & 200 & 58 & 11600 \\ 12 & \text { PS } & 1-7 & 100 & 58 & 5800 \\ 13 & \text { ES } & 1-7 & 80 & 58 & 4640 \\ 14 & \text { BPI } & 1-7 & 100 & 58 & 5800 \\ 15 & \text { KPI } & 1-7 & 100 & 58 & 5800 \\ 16 & \text { IAT } & 1-7 & 60 & 58 & 3480 \\ 17 & \text { IPII } & 1-7 & 60 & 58 & 3480 \\ & & & 4936 & & 286288\end{array}$

Dari penjumlahan di atas dijumpai kesamaan hasil penjumlahan baik dengan penghitungan secara total jumlah mahasiswa dan jumlah mata kuliah yang diambil oleh setiap mahasiswa, maupun dengan penyebaran jumlah mahasiswa dan jumlah mata kuliah ke dalam prodi masing-masing.

Maksud dari pemaparan data jumlah tersebut adalah bahwa setiap mahasiswa memiliki kebutuhan sesuai dengan jumlah mata kuliah yang harus diambilnya secara akademik. Oleh karena jumlah mahasiswa 5000 orang maka jumlah kebutuhan dikalikan dengan jumlah mahasiswa.

Kebutuhan $=($ Mahasiswa 1 X 58) $+($ Mahasiswa 2 X 58) + (Mahasiswa 3 X 58) + ... + (Mahasiswa N X 58). $N=4936$. Maka kebutuhan $=4936 \times 58=286288$ eksemplar.

\section{Penghitungan Secara Spesifik}

Penghitungan secara spesifik dimaksudkan adalah bahwa setiap mata kuliah yang diambil oleh mahasiswa tidak dibutuhkan sepanjang mahasiswa di dalam akademik, akan tetapi mata kuliah yang diberikan harus diambil oleh mahasiswa pada semester tertentu. Setelah mahasiswa menyelesaikan sebuah mata kuliah maka kebutuhannya akan berhenti. Dengan demikian penghitungan kebutuhan terletak pada berapa jumlah mahasiswa yang sedang mengambil mata kuliah tertentu.

Adapun spesifikasi kategori yang didapatkan berdasarkan keadaan mata kuliah yang harus diambil dan berdasarkan mahasiswa terbagi kepada mata kuliah IAIN, mata kuliah fakultas, dan mata kuliah prodi. 
Mata Kuliah IAIN

\begin{tabular}{|c|c|c|c|c|}
\hline \multicolumn{5}{|c|}{$\begin{array}{c}\text { No. Jumlah Mata Kuliah } \\
\text { (A) }\end{array}$} \\
\hline 1 & \multicolumn{2}{|c|}{10} & 1000 & 10000 \\
\hline \multicolumn{5}{|c|}{$\begin{array}{l}\text { Mata kuliah IAIN akan digunakan oleh mahasiswa IAIN } \\
\text { keseluruhan pada semester } 1 \text { hingga } 4 \text {, sehingga } 10 \text { mata kuliah tersebut } \\
\text { tersebar ke dalam } 3 \text { semester. Sementara yang membutuhkan mata kuliah } \\
\text { tersebut mahasiswa angkatan pertama dan kedua. Jika setiap tahun IAIN } \\
\text { menerima } 1500 \text { mahasiswa maka gambaran penyebarannya sebagai berikut: }\end{array}$} \\
\hline No. & Semester & $\begin{array}{l}\text { Jumlah Mata } \\
\text { Kuliah (A) }\end{array}$ & $\begin{array}{c}\text { Jumlah } \\
\text { Mahasiswa (B) }\end{array}$ & $\begin{array}{l}\text { Jumlah Kebutuhan } \\
\text { (AXB) }\end{array}$ \\
\hline 1 & 1 & 4 & 1000 & 4000 \\
\hline 2 & 2 & 5 & 1000 & 5000 \\
\hline \multirow[t]{2}{*}{3} & 3 & 1 & 1000 & 1000 \\
\hline & & 10 & & 10000 \\
\hline
\end{tabular}

Jumlah kebutuhan adalah (Mata Kuliah 1 X Jumlah Mahasiswa) + (Mata Kuliah 2 X Jumlah Mahasiswa) + ... + (Mata Kuliah N X Jumlah Mahasiswa). Jumlah Kebutuhan adalah N X Jumlah Mahasiswa $=10$ X 1000 $=10000$ Eksemplar.

Jika penerimaan mahasiswa berbeda setiap tahunnya, maka penghitungannya dengan melakukan penyebaran pada jumlah sesungguhnya. Sebagai contoh sebagai berikut:

\begin{tabular}{cccccc}
\hline No. & Semester & $\begin{array}{l}\text { Jumlah Mata } \\
\text { Kuliah (A) }\end{array}$ & $\begin{array}{l}\text { Jumlah } \\
\text { Mahasiswa (B) }\end{array}$ & $\begin{array}{l}\text { Jumlah } \\
(\mathrm{AXB})\end{array}$ & Kebutuhan \\
\hline 1 & 1 & 4 & 1100 & 4400 \\
2 & 2 & 5 & 1100 & 5500 \\
3 & 3 & 1 & 1000 & 1000 \\
& & 10 & & 10900 \\
\hline
\end{tabular}

Dengan demikian untuk mengukur kebutuhan bahan perpustakaan monograp perpustakaan IAIN Curup berkaitan dengan mata kuliah institusi IAIN, kepala perpustakaan, pustakawan dan pengelola perpustakaan lainnya hendaknya senantiasa menghitung kebutuhan setiap tahun. Hal ini 
dikarenakan kemungkinan terjadi perubahan jumlah mahasiswa yang diterima setiap tahun.

Jumlah kebutuhan untuk kategori mata kuliah IAIN diperhitungkan jumlah mahasiswa pada angkatan pertama dan kedua saja karena pada tahun ketiga tidak ada mahasiswa lagi membutuhkan. Dengan demikian untuk penghitungan kebutuhan pada tahun 2019, yang menjadi penghitungan adalah jumlah mahasiswa tahun 2019 dan 2018.

Mata Kuliah Fakultas

\begin{tabular}{llccc}
\hline No. & Fakultas & $\begin{array}{c}\text { Jumlah Mata } \\
\text { Kuliah (A) }\end{array}$ & $\begin{array}{c}\text { Jumlah } \\
\text { Mahasiswa (B) }\end{array}$ & $\begin{array}{c}\text { Jumlah Kebutuhan } \\
\text { (AXB) }\end{array}$ \\
\hline 1 & Tarbiyah & 8 & 600 & 4800 \\
2 & UAD & 8 & 240 & 1920 \\
3 & Syariah & 8 & 240 & 1920 \\
& & & 8640 \\
\hline
\end{tabular}

Mata kuliah fakultas akan digunakan oleh mahasiswa IAIN fakultas tertentu pada semester 1 hingga 4, sehingga 8 mata kuliah tersebut tersebar ke dalam 4 semester, dengan demikian jika dirata-ratakan setiap semester ada 2 mata kuliah. Sementara yang membutuhkan mata kuliah tersebut mahasiswa angkatan pertama dan kedua. Jika setiap tahun IAIN menerima 600 untuk Fakultas Tarbiyah, 240 untuk Fakultas UAD dan 240 untuk Fakultas Syariah maka gambaran penyebarannya sebagai berikut:

\begin{tabular}{llcccc}
\hline No. & Fakultas & Semester & $\begin{array}{c}\text { Jumlah Mata } \\
\text { Kuliah (A) }\end{array}$ & $\begin{array}{c}\text { Jumlah } \\
\text { Mahasiswa (B) }\end{array}$ & $\begin{array}{c}\text { Jumlah } \\
\text { Kebutuhan } \\
(\mathrm{AXB})\end{array}$ \\
\hline 1 & Tarbiyah & 1 & 2 & 600 & 1200 \\
2 & & 2 & 2 & 600 & 1200 \\
3 & & 3 & 2 & 600 & 1200 \\
4 & & 4 & 2 & 600 & 1200 \\
5 & UAD & 1 & 2 & 240 & 480 \\
6 & & 2 & 2 & 240 & 480 \\
7 & & 3 & 2 & 240 & 480 \\
\hline
\end{tabular}


56 | Maulana Syaid, dkk : Analisis Jumlah Kuantitatif...

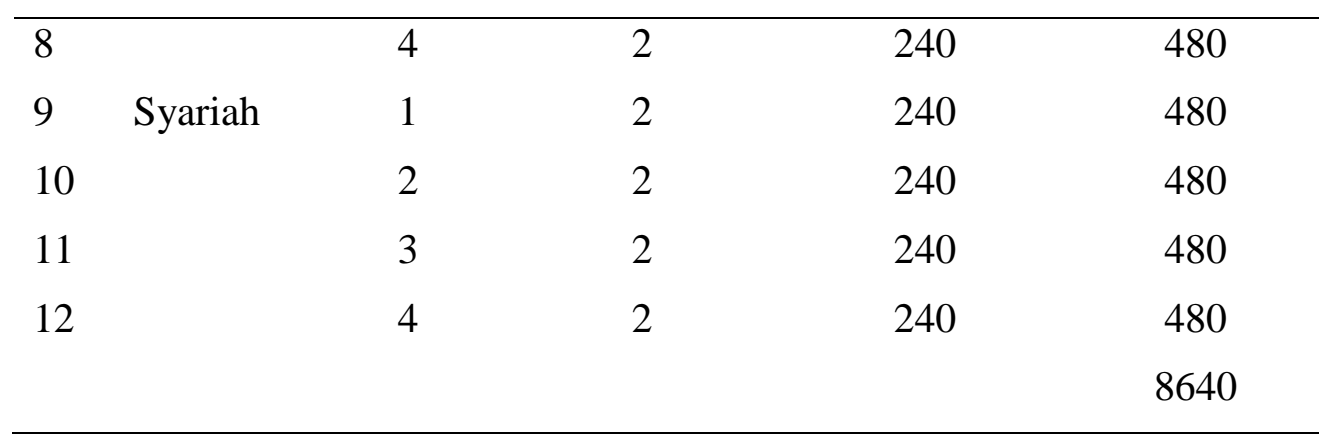

Sama halnya dengan mata kuliah IAIN, jika penerimaan mahasiswa berbeda setiap tahunnya, maka penghitungannya dengan melakukan penyebaran pada jumlah sesungguhnya.

Mata Kuliah Prodi

- Angkatan Tahun 2019

\begin{tabular}{rlccc}
\hline NO. & PRODI & $\begin{array}{c}\text { JUMLAH } \\
\text { MAHASISWA }\end{array}$ & $\begin{array}{c}\text { JUMLAH } \\
\text { MATA } \\
\text { KULIAH }\end{array}$ & $\begin{array}{c}\text { JUMLAH } \\
\text { KEBUTUHAN (EKS) }\end{array}$ \\
\hline 1 & BKPI & 32 & A & BXA \\
2 & MPI & 37 & 6 & 192 \\
3 & PAI & 236 & 6 & 222 \\
4 & BA & 21 & 6 & 1416 \\
5 & PGMI & 255 & 6 & 126 \\
6 & PIAUD & 27 & 6 & 1530 \\
7 & TBIng & 60 & 6 & 162 \\
8 & TBInd & 32 & 6 & 360 \\
9 & TM & 6 & 6 & 192 \\
10 & HKI & 38 & 6 & 36 \\
11 & HTNI & 20 & 6 & 228 \\
12 & PS & 124 & 6 & 120 \\
13 & ES & 55 & 6 & 330 \\
14 & BPI & 2 & 6 & 12 \\
\hline
\end{tabular}


Tik Ilmeu, Vol.4, No.1, 2020 |57

\begin{tabular}{lllll}
\hline 15 & KPI & 71 & 6 & 426 \\
16 & IAT & 17 & 6 & 102 \\
17 & IPII & 46 & 6 & 276 \\
& & & & 6474 \\
\hline
\end{tabular}

Angkatan tahun 2019 IAIN Curup adalah yang sedang mengikuti perkuliahan semester 1 .

- Angkatan Tahun 2018

\begin{tabular}{|c|c|c|c|c|}
\hline \multirow[t]{2}{*}{ NO. } & \multirow[t]{2}{*}{ PRODI } & \multirow{2}{*}{$\begin{array}{c}\text { JUMLAH } \\
\text { MAHASISWA } \\
\text { B }\end{array}$} & \multirow{2}{*}{$\begin{array}{c}\text { JUMLAH } \\
\text { MATA } \\
\text { KULIAH } \\
\text { A }\end{array}$} & \multirow{2}{*}{$\begin{array}{c}\text { JUMLAH } \\
\text { KEBUTUHAN (EKS) } \\
\text { BXA }\end{array}$} \\
\hline & & & & \\
\hline 1 & BKPI & 50 & 14 & 700 \\
\hline 2 & MPI & 70 & 14 & 980 \\
\hline 3 & PAI & 90 & 14 & 1260 \\
\hline 4 & BA & 30 & 14 & 420 \\
\hline 5 & PGMI & 80 & 14 & 1120 \\
\hline 6 & PIAUD & 60 & 14 & 840 \\
\hline 7 & TBIng & 80 & 14 & 1120 \\
\hline 8 & TBInd & 60 & 14 & 840 \\
\hline 9 & $\mathrm{TM}$ & 60 & 14 & 840 \\
\hline 10 & HKI & 50 & 14 & 700 \\
\hline 11 & HTNI & 60 & 14 & 840 \\
\hline 12 & PS & 60 & 14 & 840 \\
\hline 13 & ES & 60 & 14 & 840 \\
\hline 14 & BPI & 40 & 14 & 560 \\
\hline 15 & KPI & 50 & 14 & 700 \\
\hline 16 & IAT & 50 & 14 & 700 \\
\hline 17 & IPII & 50 & 14 & 700 \\
\hline
\end{tabular}


58 | Maulana Syaid, dkk : Analisis Jumlah Kuantitatif...

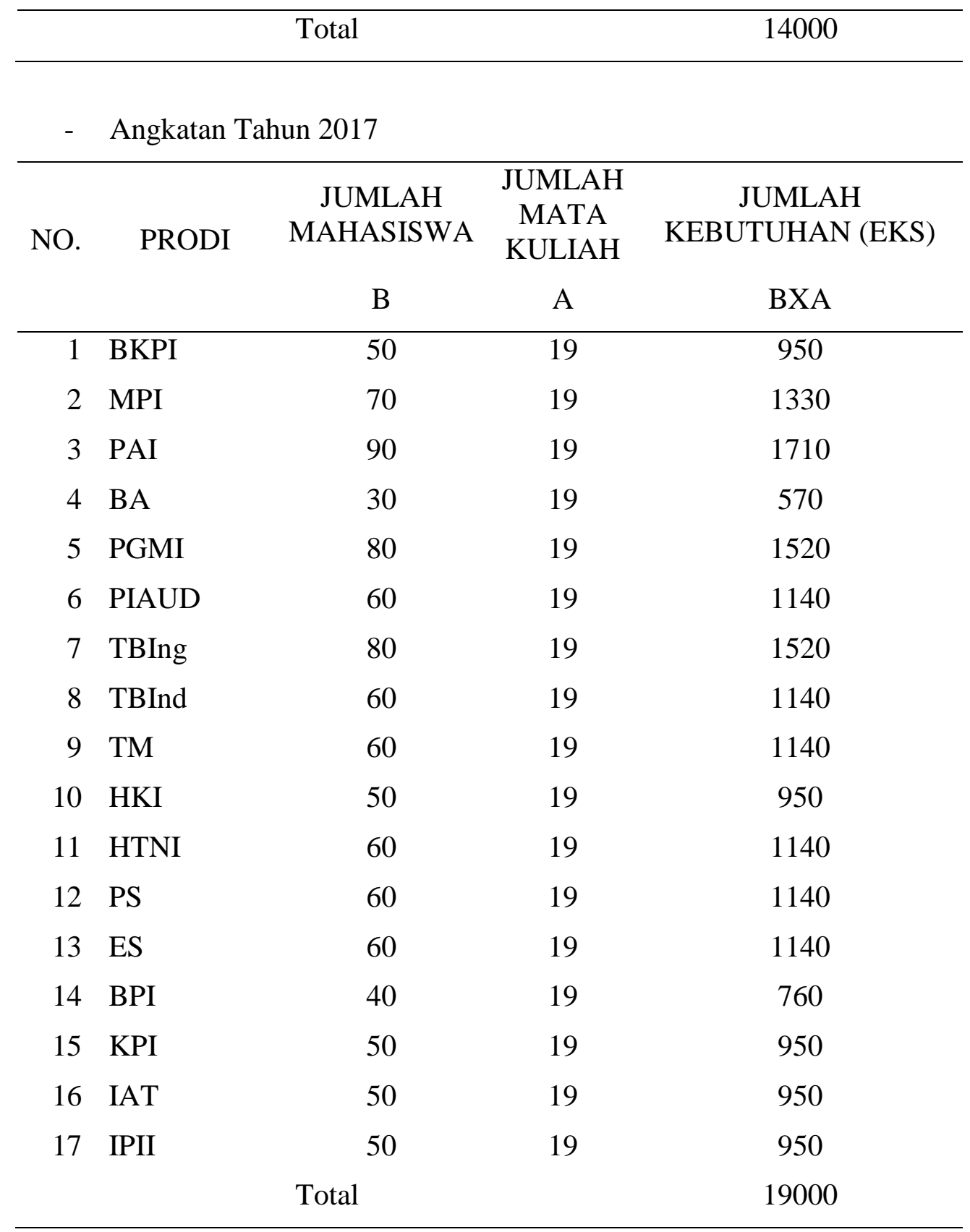


Tik Ilmeu, Vol.4, No.1, 2020 |59

- Angkatan Tahun 2016

\begin{tabular}{rlccc}
\hline NO. & PRODI & $\begin{array}{c}\text { JUMLAH } \\
\text { MAHASISWA }\end{array}$ & $\begin{array}{c}\text { JUMLAH } \\
\text { MATA } \\
\text { KULIAH }\end{array}$ & $\begin{array}{c}\text { JUMLAH } \\
\text { KEBUTHAN (EKS) }\end{array}$ \\
\hline 1 & BKPI & 50 & 1 & BXA \\
2 & MPI & 70 & 1 & 50 \\
3 & PAI & 90 & 1 & 70 \\
4 & BA & 30 & 1 & 90 \\
5 & PGMI & 80 & 1 & 30 \\
6 & PIAUD & 60 & 1 & 80 \\
7 & TBIng & 80 & 1 & 60 \\
8 & TBInd & 60 & 1 & 80 \\
9 & TM & 60 & 1 & 60 \\
10 & HKI & 50 & 1 & 60 \\
11 & HTNI & 60 & 1 & 50 \\
12 & PS & 60 & 1 & 60 \\
13 & ES & 60 & 1 & 60 \\
14 & BPI & 40 & 1 & 60 \\
15 & KPI & 50 & 1 & 50 \\
16 & IAT & 50 & 1 & 50 \\
17 & IPII & 50 & 1 & \\
& & & & 50 \\
\hline
\end{tabular}

- $\quad$ Angkatan Tahun 2016-2019

NO.

Angkatan

JUMLAH

KEBUTUHAN (EKS) 
60 | Maulana Syaid, dkk : Analisis Jumlah Kuantitatif...

\begin{tabular}{llc}
\hline 1 & Angkatan Tahun 2019 & 6474 \\
2 & Angkatan Tahun 2018 & 14000 \\
3 & Angkatan Tahun 2017 & 19000 \\
4 & Angkatan Tahun 2016 & 1000 \\
& Total & 40474 \\
\hline
\end{tabular}

Dari uraian penghitungan secara spesifik maka hasil yang diperoleh adalah:

\begin{tabular}{rcc}
\hline NO. & Kategori & $\begin{array}{c}\text { JUMLAH } \\
\text { KEBUTUHAN (EKS) }\end{array}$ \\
\hline 1 & Mata Kuliah IAIN & 10900 \\
2 & Mata Kuliah Fakultas & 8640 \\
3 & Mata Kuliah Prodi & 40600 \\
& Total & 60140 \\
\hline
\end{tabular}

\section{KESIMPULAN}

Jumlah mahasiswa IAIN Curup tahun 2019 tersebar ke dalam program studi yang ditawarkan oleh IAIN Curup. Jumlah mahasiswa IAIN Curup penerimaan tahun 2019 secara menyeluruh adalah 1079 orang dengan jumlah tertinggi pada program studi PGMI dan terendah program studi BPI. Adapun jumlah mahasiswa sebelumnya adalah 3000 mahasiswa yang tersebar ke dalam angkatan 2018, 2017 dan 2016. Dengan demikian jumlah mahasiswa yang harus dipenuhi kebutuhannya adalah 4079 mahasiswa.

Kebutuhan bahan pustaka monograp berdasarkan analisis kuantitatif jumlah mahasiswa IAIN Curup tahun 2019 adalah 60140 eksemplar. Penghitungan kebutuhan jika dilakukan secara umum adalah 286288 eksemplar. Maka dari dua teknik analisis tersebut terjadi selisih yang sangat signifikan, dengan demikian penghitungan dengan teknik general atau umum tidak dianjurkan dalam hal penghitungan kebutuhan.

Perpustakaan IAIN Curup dikategorikan belum memenuhi kebutuhan monograf pemustaka. Koleksi yang dimiliki perpustakaan IAIN Curup harus 
diteliti terlebih dahulu apakah mencerminkan kebutuhan sesungguhnya atau tidak. Jika belum mencerminkan kebutuhan sesungguhnya maka prosentase pemenuhan kebutuhan akan semakin berkurang.

\section{DAFTAR RUJUKAN}

Undang-Undang Republik Indonesia Nomor 43 tahun 2007 tentang Perpustakaan, 43 (Pemerintah Republik Indonesia 2007).

Gregory, V. L. (2019). Collection Development and Management for 21 st Century Library Collections: An Introduction. American Library Assosiation.

Iswanto, R. (2017). Kebijakan Pengembangan Koleksi dan Pemanfaatannya di Perpustakaan Perguruan Tinggi (Analisis Penerapan Kebijakan Pengembangan Koleksi Perpustakaan Utama Universitas Islam Negeri Syarif Hidayatullah Jakarta). Tik Ilmeu, 1-18.

Iswanto, R. (2017). Peningkatan Program Studi Melalui Perencanaan Strategis dalam Pemenuhan Kebutuhan Sumber Informasi Kajian Keilmuan Sivitas Akademika (Analisis Pelaksanaan di Perpustakaan Sekolah Tinggi Agama Islam Negeri Curup). Tik Ilmeu, 145-160.

Johnson, P. (2014). Fundamentals of Collection Development and Management. American Library Assosiation.

Misroni, \& Iswanto, R. (2018). Konsep Model Formulasi Rasio Kebutuhan Bahan Perpustakaan (Analisis Kuantitatif Kebutuhan Bahan perpustakaan Sekolah Tinggi Agama Islam Negeri Curup Tahun 2017). Tik Ilmeu, 109-136.

Prihandoko, A. C. (2005). Buku Rujukan PGSD Bidang Matematika : Memahami Konsep Matematika Secara Benar dan Menyajikannya dengan Menarik. Jakarta: Departemen Pendidikan Nasional. 